\title{
Understanding and Embracing Service Design Principles in Creating Effective Library Spaces and Services
}

\section{Author: Kris Johnson}

This article is $@$ Emerald Group Publishing and permission has been granted for this version to appear here (scholarworks.montana.edu).

Kris Johnson . "Understanding and Embracing Service Design Principles in Creating Effective Library Spaces and Services" In The Future of Library Space. Published online: 15 Dec 2016; 79-102. http://dx.doi.org/10.1108/S0732-067120160000036003 
Running Head: UNDERSTANDING AND EMBRACING SERVICE DESIGN PRINCIPLES

Understanding and Embracing Service Design Principles in Creating Effective Library Spaces and Services

Kris Johnson

Head, Learning and Research Services Department

Montana State University Library

Bozeman, Montana

This article is (c) Emerald Group Publishing and permission has been granted for this version to appear here (scholarworks.montana.edu). Emerald does not grant permission for this article to be further copied/distributed or hosted elsewhere without the express permission from Emerald Group Publishing Limited. DOI 10.1108/S0732-067120160000036003 


\begin{abstract}
Purpose:

The aim of this chapter is to help library administrators understand the concept of Service Design, and to maintain that any consideration of the future of library spaces should begin with a Service Design focused approach.
\end{abstract}

Approach:

The chapter is a combination of general review, literature review, case study, and conceptual paper. It focuses on describing the basics of the concept, highlighting essential resources for further understanding, highlighting Service Design specifically applied in libraries, and providing one case study of an academic library undergoing a master planning project utilizing the lens of Service Design. The chapter will conclude by emphasizing the importance of attaining an appropriate understanding and buy-in for the Service Design process by library administrators and staff in order for its effective implementation.

Practical Implications:

Practical implications to employing Service Design to library spaces are endless, and span that gamut from making smart decisions based on user input and evidence, to creating spaces and services that are relevant to library users. Employing a Service Design approach to library building projects helps administrators position themselves to advocate for needed technology and funding in the highly competitive resource arena. The ideas gleaned from this chapter can be

'This article is (C) Emerald Group Publishing and permission has been granted for this version to appear here (scholarworks.montana.edu). Emerald does not grant permission for this article to be further copied/distributed or hosted elsewhere without the express permission from Emerald Group Publishing Limited.' 
applied in any library: academic, public, special, or school. The results will be different, because every library has a unique group of users, but the processes employed are the same.

Originality:

Library literature related to Service Design is slim but slowly emerging. This chapter fills a gap in literature geared specifically to administrators as well as building design and redesign projects.

Keywords: Service design, academic library spaces, building design, library buildings, library services

'This article is (C) Emerald Group Publishing and permission has been granted for this version to appear here (scholarworks.montana.edu). Emerald does not grant permission for this article to be further copied/distributed or hosted elsewhere without the express permission from Emerald Group Publishing Limited.' 


\author{
Understanding and Embracing Service Design Principles in \\ Creating Effective Library Spaces and Services
}

\begin{abstract}
Introduction
Service design is influenced by a large spectrum of different disciplines. Psychology and sociology, because of the relational and human-intensive nature of services; interaction and communication design, because of their interactive character; management, marketing and

organization theory, because of their capacity of changing the current paradigms; and architecture, planning, environment and product design, because of their influence on the built environment. -Anna Meroni (Forlano, 2010, para. 10)
\end{abstract}

The opportunity to build a new or renovate a current library building has presented itself, but how to begin? Primers do exist, in the form of whole books that guide the process from start to finish, but mentally and conceptually, how does a busy library administrator conceive the vision for the future library space? Conversely, should the library administrator conceive this vision? A library leader’s strong presence in a library building project is essential for buy-in and understanding of library staff in the overall endeavor and ultimately, the success of the project. But should it be to create the vision for the project?

A solid visioning process is one of the first steps employed in library building projects. Visioning is effectively aided by gaining objective insights into the needs and behaviors of library users as well as the workflows of staff and their engagement with users. These insights form the foundation for the planning of the library building in the form of a vision, and can be greatly facilitated by a process called Service Design.

To circle back to the question asked at the beginning about how to start a library building project: Creating the vision by employing a Service Design approach is the first step. This

'This article is (C) Emerald Group Publishing and permission has been granted for this version to appear here (scholarworks.montana.edu). Emerald does not grant permission for this article to be further copied/distributed or hosted elsewhere without the express permission from Emerald Group Publishing Limited.' 
chapter introduces library administrators to the concept of Service Design, provides select, core resources for further information, outlines the basics of a Service Design process, and highlights one academic library undergoing a building master planning project utilizing the Service Design process. Because published literature skews towards academic examples, the focus will be on Service Design highlights from academic libraries, however, the concepts apply equally to public libraries, or any type of library for that matter. The results will be different, because every library has a unique group of users, but the Service Design processes employed will be exactly the same. The chapter concludes by advocating for the importance of administrator and staff understanding of Service Design in order to engender buy-in for the process and ultimate success of the project.

\section{Core Concepts of Service Design}

Service design is famously difficult to define and like most important things is something that is neither new nor totally unfamiliar. (Gunatillake, 2011, para. 3)

Service Design is a relatively new concept in the world of libraries, but gaining traction and prominence as its principals are being applied to the design of library spaces and services, and as practitioners introduce the concept into the library literature. Never heard of it? That's ok, as it is likely readers are familiar with the techniques used within the field because they overlap with other design fields. Service Design is part of the larger field of “design” and a lesser known cousin of the popular User Experience (UX). However, Service Design is not an extension of UX and is more encompassing and holistic in its approach, thus more broadly applicable in the context of the design of library spaces. While the formal concept of Service Design might be less familiar, techniques used in the Service Design process, things like the creation of user personas

'This article is (C) Emerald Group Publishing and permission has been granted for this version to appear here (scholarworks.montana.edu). Emerald does not grant permission for this article to be further copied/distributed or hosted elsewhere without the express permission from Emerald Group Publishing Limited.' 
or using focus groups to gain insights from users, will be familiar to administrators. It is the distinct, yet emerging field of Service Design, relatively new in the design milieu, that will be described here.

Service Design as a discipline evolved through the 1980s and 1990s with the first Service Design focused companies starting in the early 2000s and the international professional organization The Service Design Network (SDN) forming in 2004. Touchpoint: The Journal of Service Design was launched in 2009 by the SDN. In 2013 Forrester Research published The State of Service Design, 2013: A Sea of Small Agencies Delivers Strategic Customer Experience Offerings (available for $\$ 400.00$ https://www.forrester.com/The+State+Of+Service+Design+2013/fulltext/-/E-res108541), solidifying the legitimacy of the field and describing its state at the time:

“Companies need to define and implement seamless customer journeys that span time and multiple touchpoints. To help achieve that goal, this report sheds light on the current state of service design, an important but relatively obscure design subspecialty...Customer experience professionals can leverage the insights in this report to better understand the field of service design and how service design agencies can support their customer experience improvement and innovation initiatives.”

Service Design has been described in the following ways by its practitioners: As a methodology for assessment, a co-creative process, a deliberate development of a service, a design principle, a mindset and way of thinking, an attentiveness to experience, and as an approach (approach to understanding; an interdisciplinary approach; an evolving approach). All descriptions are equally true and exist simultaneously. Experts in the field agree there is no one, core definition of Service Design. For some, this suits them just fine: “A single definition of service design might constrain this evolving approach...” (Stickdorn and Schneider, 2011, p.29)

'This article is (C) Emerald Group Publishing and permission has been granted for this version to appear here (scholarworks.montana.edu). Emerald does not grant permission for this article to be further copied/distributed or hosted elsewhere without the express permission from Emerald Group Publishing Limited.' 
aligning with a core design ethos of flexibility and creativity and a premise that fields able to precisely define themselves are "lethargic, dying, or dead fields, where inquiry no longer provides challenges to what is accepted as truth” (Stickdorn and Schneider, 2011, p.289.) While an extreme and somewhat narrow view of other disciplines, the takeaway is that library administrators should feel encouraged to look on this as a positive and consider how the evolving and flexible nature of Service Design can assist in the process of discovering new ways for libraries to provide services and the buildings and digital delivery methods that provide those services. A field that is evolving and flexible, like Service Design, can assist a field like library science, which is moving forward, but arguably at a slower (some may say, considered) pace than other industries in terms of new ways of thinking, doing, and offering services. There are notable exceptions of course as changes in culture and communities are necessitating libraries to re-examine their roles and change and adapt for the times.

For laypeople and readers of this chapter however, a few definitions are necessary for better understanding of the concept or Service Design. Librarians Marquez and Downey crafted a definition based on their research of business literature and design literature: "Service design is a holistic, co-creative, and user-centered approach to understanding customer behavior for the creation or refining of services.” (Marquez \& Downey, 2015, para. 7.) In The 7 Things You Should Know About Service Design educational, library, and service design consultant Elliot Felix (2011a, p. 1.), offers this explanation: “...a process that examines the relationship between those who use a service and the service environment, which could include information, technology, furniture, physical spaces, and people. Service design focuses on human interactions at 'touchpoints,' those spots at which users intersect with other people or the environment.” Felix 'This article is (c) Emerald Group Publishing and permission has been granted for this version to appear here (scholarworks.montana.edu). Emerald does not grant permission for this article to be further copied/distributed or hosted elsewhere without the express permission from Emerald Group Publishing Limited.' 
describes Service Design in the context of learning spaces slightly differently in another article:

“...as the process of holistically designing the service interactions among people, information, technology, and space so that services are usable, useful, desirable, and effective.” (Felix, 2011b, p. 3). And finally, the SDN offers the following definition: "Service design is the activity of planning and organizing people, infrastructure, communication and material components of a service in order to improve its quality and the interaction between service provider and customers. The purpose of service design methodologies is to design according to the needs of customers or participants, so that the service is user-friendly, competitive and relevant to the customers.” (Service Design Network, n.d., para. 1.)

The last definition is particularly relevant as it includes a focus on infrastructure, which in the case of the library would be the building as well as digital touchpoints. In a building project that applies Service Design principals to the process, Service Design would generally come into play during the visioning process, a process which may play an equal or even greater role in the planning process than the traditional space programming and facility analysis. During the visioning process, Service Design projects and research would be conducted. Examples could include:

- Workshops with library, learning commons, IT staff, and/or other potential partners (writing or tutoring center; academic advising; media production) to understand service relationships. These relationships can be translated to architects as key considerations in the building design.

- Researcher observations of users, or sessions directly with users such as students and faculty to identify key moments in the user experience, which are translated into user personas, journey maps, and/or use cases. These key moments can also provide building designers with important insights useful to the architectural planning.

- Building on the step above, service blueprints may be created, which can lead to a process called service prototyping, which involves creating and testing early models of potential services prior to building design or construction in order to assess whether a service concept is sound or useful. Doing so prior to construction can save time and

'This article is (c) Emerald Group Publishing and permission has been granted for this version to appear here (scholarworks.montana.edu). Emerald does not grant permission for this article to be further copied/distributed or hosted elsewhere without the express permission from Emerald Group Publishing Limited.' 
money if the original idea was not sound, or if adjustments need to be done to refine the concept. Better to do this prior to construction than after.

"I think looking at the student current use, their need, and their expectations are so essential to designing new spaces. The architect has one vision, the administrator may have another...but only through evidence, feedback, and co-creation with our actual users can we get to something that is desired.” (J. Marquez, Personal e-mail to the author. October 20, 2015). Taking the time to carefully plan the library starting from a service perspective will ultimately result in a better product for all. A fuller understanding of the concept is necessary and there are several resources to aid in this process.

Core Resources for Further Understanding

Without a doubt, you cannot learn what service design is and how to do it just from a textbook. You need to try, fail, learn from your mistakes, improve, try again and thus educate yourself. (Stickdorn and Schneider, 2011, p. 14)

There are hundreds of readings in the area of Service Design. Business, manufacturing, computer programming, healthcare, advertising, and the hospitality industry are just a few of the fields applying the concept, and publishing the outcomes. The following core resources were selected to give a busy library administrator a solid foundation for understanding in order to embrace and move forward with the concepts in a library design or renovation process:

Articles:

Administrators should start with these four articles:

1. Elliott Felix's 7 Things You Should Know About Service Design (2011a). This short, succinct, 2-page piece written for EDUCAUSE cuts to the core of the concept, offers a scenario based example, and explains the current and future significance of service 'This article is (C) Emerald Group Publishing and permission has been granted for this version to appear here (scholarworks.montana.edu). Emerald does not grant permission for this article to be further copied/distributed or hosted elsewhere without the express permission from Emerald Group Publishing Limited.' 
design, placing the concept through the lens of creating physical environments in higher education conducive to teaching and learning.

2. Marquez and Downey's Service Design: An Introduction to a Holistic Assessment Methodology of Library Services (2015). While taking courses for his MBA, librarian Marquez came upon the service design methodology while working on a project focused on design thinking. Drawing primarily from the literature of business and design, the authors make a convincing case for the holistic integration of a library environment using the service design methodology. Published in the open source Weave: The Journal of User Experience, Marquez and Downey introduce the concept of service design to a generation of librarians heretofore focused on the user experience as applied to web design. A much welcome addition to the UX literature.

3. Mark de Jong's Service Design for Libraries: An Introduction (2014). Excellent, thorough, scholarly overview of the topic from a Service Science perspective. Argues, as does this chapter, the "emerging necessity [of implementing the concept of service design] as an administrative requisite to meet library users' needs.” Likely the first published work on the topic in the U.S. based library literature (see three 2013 Finnish articles from European based publications: Juntunen et al. (2013), Virrankoski (2013), and Sinikara (2013) for the earliest works on the topic in the library field).

4. Elliott Felix's Learning Space Service Design (2011b). Argues the necessity of adding services into the planning process along with the usual furniture, technology, and space considerations in the design of learning spaces. Includes many practical examples along with numerous illustrations and graphics. A longer and useful companion to his shorter piece for EDUCAUSE.

Books:

For administrators or another library staff person appointed to serve as a Service Design point person/resident expert, the following books are excellent starting points:

1. Løvlie, Polaine, and Reason’s Service Design: From Insight to Implementation (2013). A relative newcomer to the monographic literature in the field, this work is a mixed approach to the topic and includes some historical perspective, methodological overview, and advice and practical examples. Useful to the layperson are the inclusion of historical (to a practitioner) projects, methods, and visuals. As the authors describe it "... we wrote this book because we wanted to capture both the philosophy and thinking of service design and connect it with very practical ways of doing service design.” (p. iv).

'This article is (C) Emerald Group Publishing and permission has been granted for this version to appear here (scholarworks.montana.edu). Emerald does not grant permission for this article to be further copied/distributed or hosted elsewhere without the express permission from Emerald Group Publishing Limited.' 
2. Stickdorn and Schneider's This is Service Design Thinking (2011). The authors intended this work to be a textbook on the topic and designed it by practicing what they were preaching, by employing a service design process to create it! Longer than \#1 above, the work is divided into three main sections: Basics, Tools, and Cases. As mentioned in the introduction, Service Design stems from the larger broad field of design, and this work highlights this by including sections on Product Design, Graphic Design, Interaction Design, Social Design, Design Ethnography, Design Thinking, and more.

3. Encoding Space: Shaping Learning Environments that Unlock Human Potential, by Mathews and Soistmann (2016). The authors (a librarian and an interior designer) do not explicitly frame this book as being about service design, but they may as well have. A beautifully illustrated guide to creatively re-conceptualizing the future of library buildings, the table of contents for this book takes the form of a Journey Map and outlines concepts such as: The Importance of Place; Conceptual Transitions; Well-Being; and Radical Collaboration. The authors intend the work to serve "as the beginning of a visioning session." The publisher description sums it up by stating this book "is ideal for librarians and campus administrators looking to spark their creative thinking and push strategic conversations about the purpose, value, and future of library buildings.” Highly recommended.

\section{Websites:}

Once on board with the topic, Administrators and service design point people will benefit from familiarizing themselves with the following websites offering toolkits with step-bystep instructions on how to conduct design research as well as resources for further information.

1. Design and innovation consulting firm IDEO teamed up with The Bill and Melinda Gates Foundation to create the website: Design Thinking for Libraries: A Toolkit for Patron-Centered Libraries: http://designthinkingforlibraries.com// - Self-described as “... an approach to improving your library through creative problem solving”, this site offers a downloadable toolkit that will walk libraries step by step through the process, in three phases: Inspiration, Ideation, and Iteration. Partnering primarily with the Chicago Public and the Aarhus Public Library in Denmark, IDEO led the creation of the toolkit by working side-by-side with librarians. Created specifically for libraries.

2. Learning Space Toolkit: A Resource for Designing and Sustaining Technology-Rich Informal Learning Spaces - http://learningspacetoolkit.org/Another step by step toolkit: "North Carolina State University (NCSU) Libraries and its Distance Education and Learning Technology Applications (DELTA) are partnering with strategic consultants brightspot strategy and AECOM to design, share, and promote

'This article is (c) Emerald Group Publishing and permission has been granted for this version to appear here (scholarworks.montana.edu). Emerald does not grant permission for this article to be further copied/distributed or hosted elsewhere without the express permission from Emerald Group Publishing Limited.' 
an updated model for institutions to plan and support technology-rich informal learning spaces.” If you do not have the time to start your project from scratch, save time and follow the blueprint outlines at this site. Created specifically for institutions of higher education.

\section{The Service Design Approach}

The specifics of the SD process actually vary greatly depending on the scope of the project, the resources available to dedicate to the design, and the timeframe for actualization.

(de Jong, 2014, p. 144)

The toolkits cited previously outline step by step ways in which library lay people can implement service design projects in their libraries. The following common themes can be seen throughout all projects: 1. Inspiration, 2. Ideation, and 3. Iteration.

Two specific examples as applied to smaller scale project in libraries are recently documented, one focused on Interlibrary Loan process improvements and one on a project to combine service points in a health sciences library. de Jong and Shepard (2012) detail a service redesign project initiated to improve a document delivery service at their university, which has a strong focus on distance learning. Their article outlines in detail the inspiration, ideation, and implementation phases of their project. Through their process, the authors developed the following set of guidelines useful for others in creating better services:

1. Focus primarily and consistently on patron needs and expectations in development services and workflows. Always prioritize what is best for patrons over what is easy or familiar for library staff.

2. Cross-train all staff and flatten hierarchy - fast turnaround and high-quality customer service require that each employee have a "big picture" view of operations and assist at the point of greatest need.

3. Promote innovation by mandating professional development, encouraging autonomy and critical thinking in team members, and valuing their insights.

4. Know the potential of the technologies you are using and maximize it whenever possible to automate and streamline workflows, remove barriers to service, and to simplify the means by which patrons access these services.

'This article is (C) Emerald Group Publishing and permission has been granted for this version to appear here (scholarworks.montana.edu). Emerald does not grant permission for this article to be further copied/distributed or hosted elsewhere without the express permission from Emerald Group Publishing Limited.' 
5. Treat organizational structure and workflows as perpetual works in progress and subject to change as patron expectations alter and technology advances. (de Jong and Shepard, 2012, pp. 197-198.)

Bradigan and Rodman (2008) discuss how they applied the five steps of IDEO’s design thinking process to merge service points in their article "Single Service Point: It's All in the Design.” While this article stems from the earlier movement focused on "design thinking”, it is service design. The five steps applied to their process were: 1) understanding, 2) observing, 3) visualizing, 4) evaluating/refining, and 5) implementing. Their takeaways from the process were:

1. Redesign frequency is increasing.

2. Continuous "design thinking' is important in the daily operations of the Library to serve customers most efficiently

3. Proactive solicitation of ideas and brainstorming are valuable

4. Dramatic changes in the education setting and technology continue to influence the Library's services and resources.

Design Thinking advocate and academic library administrator Stephen Bell touted Bradigan and Rodman's article on this website Designing Better Libraries, saying “As a result I think it becomes easier to grasp how this process [IDEO’s] can help a library to identify problems and then develop appropriate solutions. Bradigan and Rodman used design thinking to first determine in what ways their patrons needed a better, more streamlined service desk. Their solutions were based on understanding and observing their library users.” (Bell, 2009, para. 4). Bell also noted at that time the dearth of articles in the library literature relating the results of design focused projects, saying “...having even more examples would be better, and in time I think there will be as librarians begin sharing their applications of design thinking in the literature” (Bell, 2009, para. 1).

'This article is (C) Emerald Group Publishing and permission has been granted for this version to appear here (scholarworks.montana.edu). Emerald does not grant permission for this article to be further copied/distributed or hosted elsewhere without the express permission from Emerald Group Publishing Limited.' 
Unfortunately, Bell’s wish hasn’t yet come fully to fruition. Because the Service Design approach is still new to the field of design, let alone the library field, finding documented examples of the process in action, especially as applied to building projects is trickier. At library conferences and via video mini-documentaries, library builders and officials from institutions having recently completed academic library buildings are reporting out on having used the process, including projects at Liberty University in Virginia, Georgia Tech, and the Hunt Library at NC State University. Unfortunately, published literature on the specifics is not yet available. Through the building of the new library at Grand Valley State University, the library also drastically changed their service model, but service design wasn’t highlighted as the technique used for doing so, yet likely followed similar principals. Their project is so new their promotion has been mainly via the aforementioned conferences presentations and online videos.

What many of these projects may have in common is the use of an outside design firm or resources within an architectural firm to guide the service design visioning process. More and more, libraries are employing these outside experts, and this approach has several advantages, centered around expertise and experience. Many such firms have worked with other libraries on similar endeavors. Through these projects they have developed a repertoire of techniques geared towards gleaning essential information from participants. Being 'outsiders' they can also be perceived as a neutral party, consultants if you will, who do not have a stake in the outcome, therefore, better able to filter through information so the end product is not biased. Service Design is complicated. Behind the scenes the people involved in the information gathering phases of the service design work must also compile the content into a final report that serves as the vision for the project. This requires a considered amount of time. Tasking that equivalent 'This article is (C) Emerald Group Publishing and permission has been granted for this version to appear here (scholarworks.montana.edu). Emerald does not grant permission for this article to be further copied/distributed or hosted elsewhere without the express permission from Emerald Group Publishing Limited.' 
amount of work to do a project in-house is possible, and doable, but libraries need to understand that to do it correctly and comprehensively it takes a lot of work and be committed to the process and necessary resources (usually staff time.) Service design is time-consuming, and potentially costly (within reason, not exorbitantly) and any library considering employing it for an overall library building master planning project will want to consider the merits and demerits of doing this in-house vs. employing an outside firm. If using an RFP (Request for Proposal) process, some architectural firms submitting bids may build in a partnership with a separate design firm into their overall proposal.

As mentioned previously, the actual process with a design firm (or an in-house, selfstyled process) will include techniques such as workshops with users and partners, user observations, stakeholder interviews, and facilitated meetings designed to build consensus. Common Service Design deliverables libraries will receive include: Service assessments, needs analyses, service blueprints, customer journey maps, ethnographic studies, concept sketches, and service mock-ups. Ultimately these deliverables will be used to help the libraries create the vision for the building project that will be incorporated into the actual building design process. Outside the common deliverables just mentioned, design firms are increasingly working with organizations to transform innovation practices and organization models: "In this case, the design deliverables are changing from finished design 'products' to 'knowledge transfer' activities such as the formalization of innovation processes, pilot projects, training sessions or design toolkits” (Forlano, 2010, para. 17). It is the latter approach that libraries can continue to embrace after a building project is completed.

'This article is (C) Emerald Group Publishing and permission has been granted for this version to appear here (scholarworks.montana.edu). Emerald does not grant permission for this article to be further copied/distributed or hosted elsewhere without the express permission from Emerald Group Publishing Limited.' 
There are many approaches a library takes to incorporating a Service Design element into the planning process for a new library building or renovation, and those approaches will vary based on library size and resources available. Libraries with fewer resources may find themselves using the tools available in the recommended resource list to tackle the project themselves, or modeling their design or projects on those reported by others once the library literature catches up. Libraries with sufficient resources are encouraged to seriously consider the difference between completing the work in-house and hiring and outside consultancy firm, and based on available resources and expertise, determine the best approach for their unique situation in order to maximize their success.

Service Design Case Study: Building Master Planning at the Montana State University Library We are increasingly expanding the spectrum of services in our buildings. From makerspaces and visualization labs to digital scholarship centers and design studios, the library landscape is changing rapidly and radically. (Mathews and Soistmann, 2016, p. 17)

During the 2015-2016 academic year the Montana State University Library (Bozeman) engaged in a Building Master Planning project, contracting with an architectural firm to prepare a vision and master plan that will serve as a template to guide either a library renovation or new build project over the decades to come. An integral part of the process was engaging with a Service Design firm that guided the visioning portion of process. This process was described by the architects in their RFP (Request for Proposal) “The ...team will work with the Library and stakeholders in a hands-on approach of building the vision, recommendations, and strategies of the master plan. Through the process, staff will learn the tools and methods [for service design].”

'This article is (C) Emerald Group Publishing and permission has been granted for this version to appear here (scholarworks.montana.edu). Emerald does not grant permission for this article to be further copied/distributed or hosted elsewhere without the express permission from Emerald Group Publishing Limited.' 
This master planning process started only after the library had engaged in several other large-scale and small-scale building projects. The Renne Library building is 129,380 square feet on four floors plus a basement. The structure includes two major components: The original brick and concrete Library (east building), constructed in 1948, and a larger concrete and steel addition, which was added to the west side of the building in 1960. In 2000, a significant retrofit project was completed to address structural upgrades, lighting, and remodeling to include life safety and accessibility features. Like many academic libraries in the early 2000’s, a Library Commons area was added to the first floor and the reference desk and collection was relocated. The library began inviting partner organizations (IT, Writing Center, Tutoring, and the Testing Center) into the building, and spaces were built to accommodate them. Most recently, a major materials deselection project allowed for the removal of library shelving adjacent to prime window spaces in the building, resulting in refreshed study spaces with new carpet, paint, and modern furniture to accommodate users, and most importantly view of the campus and adjacent mountains. Excited by the progress and reaction from users, the plan was to move next to rethinking and upgrading staff spaces and offices, as well as creating a single service point on the first level. It was at this point that MSU Campus Planning, Design \& Construction office stepped in and recommended the library engage in a master planning process. Because the previous building projects had occurred under the auspices of three separate library deans, all with varying visions, and because some projects were more complicated than others, creating dependencies on key infrastructure such as HVAC, it was the recommendation from campus MSU Campus Planning, Design \& Construction that the library take a break, engage in a systematic planning process, then move forward again using a cohesive and comprehensive plan, a plan that would 'This article is (C) Emerald Group Publishing and permission has been granted for this version to appear here (scholarworks.montana.edu). Emerald does not grant permission for this article to be further copied/distributed or hosted elsewhere without the express permission from Emerald Group Publishing Limited.' 
guide future architects and engineers according to an organized vision and plan. Thus the start of the master planning project.

A Request for Proposal (RFP) was written and opened to respondents in late spring 2015.

Some key language from the RFP included:

"Montana State University is seeking professional planning services of a qualified consultant, experienced with academic library planning and design to develop a vision and master plan for the future of the existing library building. The planning process will include consideration of the evolving role of the library and ITC and will reinforce their commitment to serve students, faculty, and staff, while actively participating in the preservation and advancement of Montana's economy and society.

The master plan will articulate current and future best practices in pedagogy and scholarship, information and content management, and identify new roles such as the organization and production of content. The master plan will also provide a road map for the organization, layout, and use of the physical and digital space and the deployment of technology that will best support the library and ITC for next 10-20 years.

The consultant(s) will develop a clear, yet flexible path that supports teaching and learning, research service, and engagement with the campus community. The path will identify and provide enumerated, phased, implementation steps with metrics for measuring the goals of the plan. To develop this road map, an interactive and participatory process with the campus community will be necessary.”

Six responses were received, all from national firms, and in early August two were invited to campus for in-person presentations. Highlights from the written response of the selected respondent included:

“...a successful master plan and renovation must start with visioning. [Our] team will work with the Library and your stakeholders in a hands-on approach of building the vision, recommendations, and strategies of the master plan. Through the process, staff will learn the tools and methods we use. We anticipate that user research and visioning phases will overlap so that findings and subsequent directives from each can inform and validate the other. Space, service, and staffing strategy will also develop in parallel to these phases.

Our methodology involves four overarching stages: 1) research and investigation, 2) visioning, 3) explorations and concept design, and 4) mapping of the deliverables. The

'This article is (C) Emerald Group Publishing and permission has been granted for this version to appear here (scholarworks.montana.edu). Emerald does not grant permission for this article to be further copied/distributed or hosted elsewhere without the express permission from Emerald Group Publishing Limited.' 
ultimate end goal is to leave the University with a document that clearly outlines a series of achievable renovations - remaking the library into an effective academic center supporting both students' needs and the mission of the University. The deliverables will document the processes used, develop space planning and operational program statements, and define conceptual design planning options in three-dimensional graphic images. Supported by the facility assessment (building systems, envelope, and code compliance), a realistic opinion of cost will be developed to define the project budget and, if necessary, organize the phases by which the facility renovations can be realized.”

Key components of the respondent's bid were the architectural firm's partnership with a Montana engineering firm as well as a nationally known service design firm. Because the work of the engineering firm was done separately from the visioning process guided by the Service Design firm, it will not be detailed here. However, it is important to note that the resulting report from the engineers will play an important role in the final master plan, as key infrastructural issues identified by the engineers will need be addressed sequentially and/or in tandem with the other building related work. The lens for the engineering work, however, did not include a Service Design component, thus its exclusion here.

The project kicked off on October $1^{\text {st }}$ with a visit to campus by representatives from the architectural firm, engineering firm, and Service Design firm. A daylong series of events started with a tour of campus and newly renovated spaces and new buildings, as well as a tour of the entire library building. Next the group met with the master plan "Steering Committee” a group of 12 individuals comprised of key library and IT personnel and two campus architects. The purpose of this meeting was to discuss goals and expectations for the project and to bring to light any "off the table” topics, meaning anything key leadership see as not feasible, possible, or wanted for our campus. (For example, it was determined that a robotic materials retrieval system was an off the table discussion topic for our library.) This discussion was followed by

'This article is (c) Emerald Group Publishing and permission has been granted for this version to appear here (scholarworks.montana.edu). Emerald does not grant permission for this article to be further copied/distributed or hosted elsewhere without the express permission from Emerald Group Publishing Limited.' 
presentations from the Director of Student Success and an Associate Provost, who talked about MSU student culture, identity, and challenges, as well as MSU's mission and future vision. At this point in the day the service design consultants led the group in two high level visioning activities: (1) Trends and (2) Service Model Metaphors. Thus began the service design focused work of the master plan. Through the use of these two exercises with the Steering Committee, the design firm started the process of utilizing the high level visional activities that would be used in future visioning workshops with stakeholders during subsequent visits to campus.

This kick-off day for the master plan project was categorized as being part of the “understanding” phase of the service design portion of the project. In general, a Service Design process will encompass the following seven phases:

1. Understanding (Research)

2. Visioning (Why)

3. Service Offerings (What)

4. Service Delivery Planning (Who)

5. Service Delivery Planning (Where)

6. Service Delivery Planning (How)

7. Service Implementation

Three more events fell under the "understanding” phase of the project and preceded the next visit to campus by the consultants:

1. A group trip to Grand Valley State University on October 19. This was known as a benchmarking trip (to a newly built space that could serve as a potential comparison space for the MSU Library), and was attended by six Steering Committee members, one architect, and one service design consultant.

2. The completion of a Current Service Location Planner, a detailed spreadsheet outlining every service currently offered within the Renne Library building, its location, hours of availability, whether digital or physical, self-service or staffed by personnel. (Completed by the author of this chapter.)

'This article is (C) Emerald Group Publishing and permission has been granted for this version to appear here (scholarworks.montana.edu). Emerald does not grant permission for this article to be further copied/distributed or hosted elsewhere without the express permission from Emerald Group Publishing Limited.' 
3. Five hour-long user persona interviews conducted by members of the library's Design Research Working Group (including the author of this chapter.) Faculty from STEM focused disciplined were interviewed according to template provided by the Service Design firm, the sessions were recorded, then later transcribed back into the interview template. Key components of the interviews included asking about key successes experienced by the individuals at work, key challenge and/or current unmet needs, and lastly, the role of the library in their work.

The bulk of the Visioning (Why) work for the project occurred on November 18-20 when two service design consultants and two architects returned to campus for hands-on, participatory workshops with stakeholders. Over three intensely focused days, they conducted visioning and UX (user experience) sessions with library personnel, campus faculty, and students. In total, they engaged with around 20 library classified staff, 20 library faculty, 14 students, 12 faculty, and 7 campus IT personnel. The Service Design methods used in these sessions included the following exercises:

1. Vision Cards: An icebreaker exercise designed to elicit blue sky thinking and key language comparing the present library to a dreamed-of future library.

2. Headlines: Another blue-sky thinking exercise designed to elicit explicit language used to describe dreamed-of library of the future.

3. Trends - I Second That: A list of controversial statements that force participants to take a stand on key questions, statements, or trends.

4. Keep - Toss - Create: An exercise that allows stakeholder to say what they like about the library and they want to keep, what they want to get rid of, and new things they want to create.

5. Ideal User Experience Mapping: A process by which participants have to choose a journey (something to be accomplished in the library) then map that journey according to five touchpoints: Entice, Enter, Engage, Exit, and Extend.

Tools used for the exercises included lots of colored Post-it notes, whiteboards, and large Post-it notes taped to the walls. All "artifacts” were saved and/or photographed by the Service Design consultants for further note-taking and synthesis. In addition to the on-site workshops, this synthesis was a key component of the work provided by the Service Design firm and

'This article is (C) Emerald Group Publishing and permission has been granted for this version to appear here (scholarworks.montana.edu). Emerald does not grant permission for this article to be further copied/distributed or hosted elsewhere without the express permission from Emerald Group Publishing Limited.' 
eventually informed the final report they wrote for the project. Key components of synthesizing service design feedback include:

1. Identify patterns and themes.

2. Sharing those patterns and themes back to the stakeholders, or the client (the library) for clarification or further understanding. Steps \#1 and \#2 could occur several times in a cycle until all parties felt understanding was achieved.

3. Understanding organizational implications, meaning, not everything is space related. Through steps \#1 and \#2 and over time with working with stakeholder or the client (the library) service designers may unearth hidden or other factors that will ultimately impact the reality of achieving a shared vision.

4. Making decisions based on previously defined priorities - Or set priorities and make decisions. Moving forward and ultimately taking action will involve decision making. (As described earlier in the chapter, Service Design is more of an art than a science. While certain common techniques can be employed, ultimately every situation is unique and will require humans to make the final decision. The key part of Service Design then is having as much user centered information at the disposal of the decision-makers in order to make the best decisions.)

Also during the Nov. 18-20 visioning session with stakeholders, four one-on-one conversations with key campus leadership occurred, the purpose of which was to understand their vision for the Library, and the desired outcomes for the project. Similar to the user persona interviews described earlier, these interviews were specifically designed to gather input from key leadership, including the President and Provost, on the vision, culture, drivers of change, and opportunities and challenges for the future Renne Library building. The Key Interview notes were divided into four quadrants: (1) The Current Situation; (2) The Changing Context; (3) The Vision for the Future; and (4) How to Get There.

After the Visioning trip, and prior to their next trip to campus, the consultants drafted a Vision Statement for the project and presented it to the Steering Committee. The Vision Statement was one of several documents drafted as a result of the visioning workshops, Key Interviews, and User Personal interviews. The draft of the Vision Statement went through several 'This article is (C) Emerald Group Publishing and permission has been granted for this version to appear here (scholarworks.montana.edu). Emerald does not grant permission for this article to be further copied/distributed or hosted elsewhere without the express permission from Emerald Group Publishing Limited.' 
iterations as the Steering Committee and key library leadership asked clarifying questions and provided feedback. The final document clarified the distinction between the Vision for the Master Plan and the organizational vision already in place for the library, and detailed seven Vision Principles. Each Vision Principle included 3-4 bullet points outlining specifics of the principle. Here is an example of one of the Principles:

- Vision Principle: Identify partnerships that will allow the Library to expand offerings related to student success and showcase the diversity of work within the University, especially related to digital tools. Key Components:

o Student Success

- Significantly expand the offerings of partners, including ITC, to support academic success and digital literacy

o Discovery Center

- Introduce all students to the resources available across MSU that support creating and making

- Provide guidance to students and instructors learning how to use the available digital tools for data research, analysis, and visualization

- Create event and program space for sharing the diversity of University innovation and showing its real world impact

o Faculty Excellence

- Offer integrated services to support innovation in pedagogy, sending a clear message that the Library is not just for students

- Support faculty in digital scholarship to support innovative research

Service Offerings (What) and Service Delivery Planning were the focus of the service design consultants and architects third visit to campus on December 16-17. During another intense series of workshops over the entire two days, the consultants worked exclusively with a group of individuals specially selected to form a Service Design Task Force (SDTF). The Task Force comprised eleven individuals: four library faculty, two library faculty/department heads, four library classified staff, and one professional IT staff member.

'This article is (C) Emerald Group Publishing and permission has been granted for this version to appear here (scholarworks.montana.edu). Emerald does not grant permission for this article to be further copied/distributed or hosted elsewhere without the express permission from Emerald Group Publishing Limited.' 
Prior to the workshops, the SDTF was asked to read two articles on service design and familiarize themselves with the Master Plan Vision Statement and Vision Principles, the latter representing the syntheses of prior work meant to inform the work of the SDTF over the coming two days. Three service design consultants guided the group through the following activities:

- Good and Bad Service Experiences / The 5 E’s of Service (Entice, Enter, Engage, Exit, and Extend)

- Value Propositions

- $\quad$ Service Delivery Trends

- Service Location Planners

Similar to the Visioning Workshop, tools used included more colored Post-it notes, whiteboards, and large Post-it notes taped to the walls, with the artifacts saved or photographed by the service design consultants for further note-taking and synthesis.

The objectives for the work with the SDTF were the following:

1. Reflect on service experiences and user feedback to describe what good service will look like in the future Library.

2. Generate a service philosophy, describing how services will be delivered and why.

3. Determine the services and programs that will be offered in the new Library, organizing current services into groupings (or service categories) so that you can describe at a high level what the Library offers, and identify any gaps in the current service portfolio.

4. Determine the number and type of service points (locations where support will be offered in the new facility), identify key adjacencies between service points, and describe the activities, people, technology and tools that are required at each service point.

5. Map out, in detail, how services will be delivered in the new library to inform staffing, technology and space design.

In reality, two days was not enough time to complete all five objectives, with

approximately $70 \%$ of the work being completed. The eventual outcomes from the work of the

SDTF were to be the creation of:

1. A Service Philosophy

2. Service Delivery Principles

3. Service Portfolio (Immediate, Short Term, Long Term)

'This article is (C) Emerald Group Publishing and permission has been granted for this version to appear here (scholarworks.montana.edu). Emerald does not grant permission for this article to be further copied/distributed or hosted elsewhere without the express permission from Emerald Group Publishing Limited.' 


\section{Service Categories; Next Steps}

After returning from what was to be their last trip to campus, the consultants fleshed out an outline for the service philosophy and service delivery principals based on workshop feedback, and similar to the Vision Statement and Principles shared it with the Steering Committee for comment, review, and editing. Concurrent to this work the Associate Dean and the author completed the Future Service Location Planner, a spreadsheet similar to the Current Service Location planner but informed by feedback from the work with the SDTF and meant to be the blueprint for designing services and service location for a new or renovated library.

During the month of January 2016 the service design consultants then synthesized everything from their work on the project since October in to a Final Report, the "Space and Service Visioning Report”, a 36-page report encompassing the following sections:

1. Introduction: An overview of the project and the process employed for the Service Design portion of the project.

2. Vision: The space and service vision, including the seven vision principles.

3. Service Philosophy: Including the Service Delivery Principles.

4. Service Portfolio: Future Service Categories; the role of partners; the future service location planner.

5. Service Delivery \& Spaces: A Service Point Strategy; Future Service Points;

6. Next Steps: Information in Pilots \& Prototypes; Assessing Services and Service Delivery;

7. Appendix: MSU Library Mission \& Vision; Text from the five key Leadership Interviews; Text from the five user personal interview with STEM faculty

Also during January, the library received the "Strategic Facility Infrastructure Assessment” report from the engineering firm. In February one architect made a trip back to campus to engage in a series of “Deep Dive” interviews with library department heads, key personnel from current library partners (Writing Center, etc.) and potential future partners (Center for Faculty Excellence), library faculty, and library event planners. The purpose of the 'This article is (C) Emerald Group Publishing and permission has been granted for this version to appear here (scholarworks.montana.edu). Emerald does not grant permission for this article to be further copied/distributed or hosted elsewhere without the express permission from Emerald Group Publishing Limited.' 
deep dive conversations was to learn first-hand to perceived space needs for these areas and to have guided walk-throughs in the current space to understand dependencies.

Armed with the two reports and the notes from the deep dive interviews, the work of the architects began in full. The Service Design phase was over and the work to plan out future spaces beginning, with the entire project being around 2/3 of the way towards completion at this point. In March the architects presented the first version of what was known as the Program Draft, which included a list of seventeen major architectural goals along with a proposed outline of space with current and proposed square footages for each space, including the service points outlined from the service design work. Again, as with previous reports, this draft was presented to the Steering Committee for comment and review. The draft was also shared with all department heads for comment and some library faculty and staff. Comments and questions were shared back to the architects, with several more iterations of the document being presented up until the next in-person visit by the architects in late April to work with the Steering Committee in a one-day live design workshop. During the live design workshop 3-D modeling software was used to manipulate floor plans in real-time as feedback and conversation ensured from members of the committee. The process was engaging and interactive and brought together all the work done to-date in a visual form that helped the group to better visualize the future library.

As of this writing, the final master plan has not yet been completed, with the live design workshops being so recently completed. In the context of this chapter, it is hoped that the process detailed here will give the reader a fuller understanding of the role of the Service Design process in the overall master planning process, the detail of work required and in-depth time spent in analysis and synthesis. When asked about the process and whether they preferred employing a

'This article is (C) Emerald Group Publishing and permission has been granted for this version to appear here (scholarworks.montana.edu). Emerald does not grant permission for this article to be further copied/distributed or hosted elsewhere without the express permission from Emerald Group Publishing Limited.' 
Service Design lens to a building master planning project, one of the architects commented: "We do like it - we think it has become essential, and we now offer service design as part of predesign services.” Adding “We see the visioning process key to exploring the relationship of service models with the entire user experience. It has become fundamental to creating the architectural designs that will help libraries reach their future. Without this [Service Design], we would be in danger of using outdated standards to create ineffective spaces.”

Importance of Understanding for Buy-in and Success

Service design is the activity of planning and organizing people, infrastructure, communication and material components of a service in order to improve its quality and the interaction between service provider and customers. (Service Design Network, n.d., n.p.)

The process of designing a new or renovating an existing library structure offers built-in opportunities to incorporate other changes within an organization. In addition to the servicebased changes that will naturally arise out of the Service Design process, other opportunities include rethinking and restructuring staff roles and responsibilities, shifting departmental structures, or evaluating staff spaces in relation to services or other departments. These built-in opportunities may be the easiest to implement because it will likely become apparent to library staff as to their benefits in relation to the library's vision for the new space. What will be harder for staff to grasp will be the concepts behind the vision, particularly one rooted in the Service Design philosophy. Hiring a design firm to guide the process is important, but because services will extend well beyond the time the library is built and after the design firm departs the process, it is essential for staff to also understand the concepts of Service Design. Library leadership will

'This article is (C) Emerald Group Publishing and permission has been granted for this version to appear here (scholarworks.montana.edu). Emerald does not grant permission for this article to be further copied/distributed or hosted elsewhere without the express permission from Emerald Group Publishing Limited.' 
spearhead the process of helping staff to understand how Service Design ties to the overall vision.

Once a library administrator is convinced of the important of Service Design it will be important to outline a plan for communication and working with staff for buy-in and support. This is important because in addition to acting as Chief Executive Officers for the library, the head administrators must also act as Change Agents in Chief: "This description fits any library director who seizes the opportunity presented by a new building to do things differently and, perhaps, better" (Bazillion and Braun, 2001, p. 167). For change to happen, a change agent must have an active presence in that process. Steven Carr advocated for this library-wide approach and the role of staff in this process this in his chapter "Refining the Customer Service Attitude":

"Every aspect of our library's service program needs to be examined, integrated, and harmonized to be truly effective. Given this concept, customer service is an enterpriselevel endeavor. Hence, it needs to be a prominent focus of organizational development in our libraries." (Carr, 2014, p. 116)

Administrators need to champion this effort and Service Design can help by infusing the philosophy throughout an enterprise such as a library, which tend to develop service in silos, often simply based on organization structure, but often based on attitude and institutional philosophy:

"Librarians are not new to designing or assessing services, but we tend to develop each service in isolation from the other services we offer and with little to no user input prior to implementation. For example, circulation policies are usually developed by circulation staff and then distributed to the rest of the library staff. Likewise, interlibrary loan, reference, collection development, and so on all tend to focus on their own policy development. The way librarians typically bring services together is to communicate with one another what each department has decided and then get user feedback by assessing services after they are in place. Service design demands that we look at our seemingly

'This article is (c) Emerald Group Publishing and permission has been granted for this version to appear here (scholarworks.montana.edu). Emerald does not grant permission for this article to be further copied/distributed or hosted elsewhere without the express permission from Emerald Group Publishing Limited.' 
disparate services as a whole entity and from users' perspectives so that the service is 'compelling and indispensable [and] delights the user'”. (Marquez and Downey, 2015, para. 5)

Administrators are encouraged to use Marquez and Downey's article as a foundational tool to start the conversation about Service Design with their staff. Aligned with the building design process, administrators can appoint "design" point people in the library, advocates of the philosophy willing to learn more and find additional ways to incorporate the techniques into smaller, more discrete projects. Because Service Design is an emerging topic, there are numerous research and publication opportunities available for librarians and staff needing to fulfill professional development requirements. Informal, periodic service design check-ins should be scheduled throughout the year to keep the concept from losing momentum and remind staff of its importance, and the lead administrators should play a role in those conversations. The latter is important because if administrators pay only lip service to the concept, staff will be less likely to embrace it and may see it simply as another in a services of "management tools" that come and go in the lifecycle of a library organization.

Service Design holds great possibilities of transforming libraries. When employed, the holistic approach to the user's experience as it relates to all aspects of a library, both physical and digital, and the co-creative processes used to gather evidence and inform will help libraries move forward as active change agents in the larger ecosystems in which they exist.

'This article is (C) Emerald Group Publishing and permission has been granted for this version to appear here (scholarworks.montana.edu). Emerald does not grant permission for this article to be further copied/distributed or hosted elsewhere without the express permission from Emerald Group Publishing Limited.' 


\section{References}

Bazillion, R. and Braun, C.L. (2001). Academic libraries as high-tech gateways: A Guide to design \& space decisions (2nd ed.). Chicago, IL: American Library Association.

Bell, S.J. (2008). Design thinking. American Libraries, 39 (1-2), 44-9.

Bell, S.J. (2009). Using design thinking at your library. Designing Better Libraries. Retrieved from http://dbl.lishost.org/blog/2009/04/03/using-design-thinking-at-yourlibrary/\#.VjTVJrerTZ4. Accessed on April 3.

Bradigan, P.S. \& Rodman, R.L. (2008). Single service point: It's all in the design. Medical Reference Services Quarterly, 27(4), 367-378, doi: 10.1080/02763860802367755

Carr, S. (2013). Refining the customer service attitude. In A. W. Stewart, C. WashingtonHoagland, \& C.T. Zsulya (Eds), Staff Development: A Practical Guide (4th ed. pp. 113125). Chicago, IL: American Library Association.

de Jong, M. (2014). Service design for libraries: An introduction. In A. Woodsworth \& W. D. Penniman (Eds.), Advances in librarianship (Advances in Librarianship, Volume 38, pp.137 - 151). Bingley, UK: Emerald Group Publishing Limited. doi: 10.1108/S0065283020140000038003

de Jong, M. and Shepard, R. (2012). The DocumentExpress model: Proposals for improving interlibrary loan and document delivery services. Journal of Access Services. 9 (4), 187199. doi:10.1080/15367967.2012.713226

Felix, E. (2011a). 7 things you should know about service design, from the EDUCAUSE Learning Initiative (ELI). Retrieved from https://net.educause.edu/ir/library/pdf/ELI7077.pdf

'This article is (C) Emerald Group Publishing and permission has been granted for this version to appear here (scholarworks.montana.edu). Emerald does not grant permission for this article to be further copied/distributed or hosted elsewhere without the express permission from Emerald Group Publishing Limited.' 
Felix, E. (2011b). Learning space service design. Journal of Learning Spaces, 1 (1). np. Retrieved from http://libjournal.uncg.edu/jls/article/view/284

Felix, E. (2015). Rethink the staff workplace: Library by design, spring 2015. Library Journal, Spring. Retrieved from http://lj.libraryjournal.com/2015/05/buildings/lbd/rethink-the$\underline{\text { staff-workplace-library-by-design-spring-2015/ }}$

Forlano, L. (2010). What is service design? Urban Omnibus (Architectural League's online publication), Retrieved from http://urbanomnibus.net/2010/10/what-is-service-design/ . Accessed on October 27.

Gunatillake, R. (2011). Why service design is the next big thing in cultural innovation. The Guardian. Retrieved from http://www.theguardian.com/culture-professionalsnetwork/culture-professionals-blog/2011/dec/08/service-design-next-big-thing . Accessed on December 8.

Juntunen, A., Nygrén, U. and Saarti, J. (2013). Reinventing the academic library and its mission: Service design in three merged Finnish libraries. In A. Woodsworth, W. D.Penniman (Eds.), Mergers and Alliances: The Wider View (Advances in Librarianship, Volume 36, pp.225 - 246). Bingley, UL: Emerald Group Publishing Limited. doi: 10.1108/S00652830(2013)0000036011

Løvlie, L., Polaine, A., \& Reason, B. (2013). Service Design: From Insight to Implementation. New York, NY: Rosenfield Media, LLC.

Marquez, J \& Downey, A. (2015). Service design: An introduction to a holistic assessment methodology of library services. Weave: Journal of Library User Experience, 1 (2), doi: http://dx.doi.org/10.3998/weave.12535642.0001.201

'This article is (C) Emerald Group Publishing and permission has been granted for this version to appear here (scholarworks.montana.edu). Emerald does not grant permission for this article to be further copied/distributed or hosted elsewhere without the express permission from Emerald Group Publishing Limited.' 
Mathews, B. \& Soistmann, L.A. (2016). Encoding Space: Shaping Learning Environments that Unlock Human Potential. Chicago, IL: Association of College and Research Libraries, a Division of the American Library Association.

Service Design Network. (n.d.). What is service design. Retrieved from http://www.servicedesign-network.org/intro/

Sinikara, K. (2013). Service design and collaboration. Scandinavian Public Library Quarterly, 46.2: 4-6. Retrieved from http://slq.nu/?article=volume-46-no-2-2013-8

Stickdorn, M. \& Schneider, J. (2011). This is service design thinking. Hoboken, NJ: Wiley. Virrankoski, A. (2013). Service design has brought a new working culture. Signum 3, 5-7.

'This article is (C) Emerald Group Publishing and permission has been granted for this version to appear here (scholarworks.montana.edu). Emerald does not grant permission for this article to be further copied/distributed or hosted elsewhere without the express permission from Emerald Group Publishing Limited.' 